\title{
Perbedaan Rerata Kadar Profil Lipid pada Preeklampsia dengan Kehamilan Normal pada Etnik Minangkabau
}

\author{
Helen Evelina Siringoringo ${ }^{1}$, Yusrawati ${ }^{2}$, Eva Chundrayetti ${ }^{3}$
}

\begin{abstract}
Abstrak
Preeklampsia-eklampsia sampai saat ini masih merupakan disease of theory. Kelainan yang terjadi pada penyakit ini adalah disfungsi endotel yang dapat disebabkan oleh perubahan kadar profil lipid. Tujuan penelitian ini adalah mengetahui perbedaan rerata kadar profil lipid pada preeklampsia dengan kehamilan normal pada etnik Minangkabau. Penelitian observasional dengan rancangan cross sectional ini dilakukan di RSUP dr. M. Djamil Padang, RS Reksodiwiryo Padang dan UPTD Laboratorium Kesehatan Daerah Sumatera Barat. Subjek terdiri dari 2 kelompok yang diambil secara consecutive sampling dengan jumlah masing-masing 27 orang. Pemeriksaan profil lipid dilakukan dengan metode kalorimetri. Analisis data dilakukan secara uji statistik independent $t$-test. Hasil penelitian diperoleh rerata kadar total kolesterol pada kelompok preeklampsia dan kehamilan normal adalah $270,19 \pm 68,955$ $\mathrm{mg} / \mathrm{dL}$ dan $247,56 \pm 44,415 \mathrm{mg} / \mathrm{dL}$ dengan nilai $\mathrm{p}=0,158$, rerata kadar trigliserida pada kelompok preeklampsia dan kehamilan normal adalah 296,07 $\pm 157,993 \mathrm{mg} / \mathrm{dL}$ dan $272,89 \pm 84,608 \mathrm{mg} / \mathrm{dL}$ dengan nilai $\mathrm{p}=0,504$, rerata kadar $\mathrm{HDL}$ pada kelompok preeklampsia dan kehamilan normal adalah $51,93 \pm 19,882 \mathrm{mg} / \mathrm{dL}$ dan $63,33 \pm 11,222 \mathrm{mg} / \mathrm{dL}$ dengan nilai $\mathrm{p}=0,012$, rerata kadar $\mathrm{LDL}$ pada kelompok preeklampsia dan kehamilan normal adalah $159 \pm 52,038 \mathrm{mg} / \mathrm{dL}$ dan $129,67 \pm 38,692 \mathrm{mg} / \mathrm{dL}$ dengan nilai $\mathrm{p}=0,023$, rasio perbandingan $\mathrm{LDL} / \mathrm{HDL}$ pada kelompok preeklampsia dan kehamilan normal adalah 3,86 dan 2,04. Dari hasil penelitian dapat disimpulkan pada kedua kelompok tidak ada perbedaan kadar kolesterol total dan trigliserida, tetapi ada perbedaan kadar HDL dan LDL, rasio perbandingan LDL/HDL lebih tinggi pada preeklampsia daripada kehamilan normal.
\end{abstract}

Kata kunci: preeklampsia, total kolesterol, trigliserida, HDL, LDL, etnik Minangkabau

\begin{abstract}
Preeclampsia-eklampsia still being a disease of theory. One of abnormality accured in preeclampsia is endothelial disfunction that is caused by changes in lipid profile. The objective of this study was to find out the difference of lipid profile mean level in preeclampsia and normal pregnancy at Minangkabau Ethnic. This was an observational study with cross-sectional design at dr. M.djamil Padang Hospital, dr Reksodiwiryo Hospital and UPTD regional health laboratory of West Sumatera. The subjects consist of two groups, choosen by consecutiteve sampling. Each group consist of 27 subjects. Lipid profile was examined by using independent calorimetric methode. The data analyzed statistically by independent t-test. The result of this study showed mean level of total cholesterol in preeclamsia and normal pregnancy were $270.19 \pm 68.955 \mathrm{mg} / \mathrm{dL}$ and $247.56 \pm 44.415 \mathrm{mg} / \mathrm{dL}$ with $p$-value 0.158 . The mean levels of triglyceride in preeclampsia and normal pregnancy were $296.07 \pm 157.993$ and $272.89 \pm 44.415 \mathrm{mg} / \mathrm{dL}$ with p-value 0.504 . The mean level of HDL in preeclampsia and normal pregnancy were $51.93 \pm 19.882 \mathrm{mg} / \mathrm{dL}$ and $63.33 \mathrm{mg} / \mathrm{dL} p$-value 0.012 . The mean level of $L D L$ in two groups were $159 \pm 52.038 \mathrm{mg} / \mathrm{dL}$ and $129.67 \pm 38.692 \mathrm{mg} / \mathrm{dL}$ with $p$-value 0.023 and the mean levels of LDL/HDL ratio were $3.86 \pm 3,09 \mathrm{mg} / \mathrm{dLin}$ preeclampsia and 2,08 $\pm 0,64$ in normal pregnancy. It can be concluded that there is no significant difference in total cholesterol and triglyseride between preeclampsia and normal in HDL and LDL and there is significant difference in LDL/HDL ratio between preeclampsia and normal pregnancy at Minangkabau Ethnic.
\end{abstract}

Keywords: preeclampsia, total cholesterol, triglyceride, HDL, LDL, Minangkabau Ethnic 
Affiliasi penulis: 1. Program Studi Magister Kebidanan FK UNAND (Fakultas Kedokteran Universitas Andalas Padang), 2. Bagian Obsetri Ginekologi FK UNAND/RSUP dr. M.Djamil Padang. 3. Bagian IImu Kesehatan Anak FK UNAND/RSUP dr. M.Djamil Padang

Korespondensi : Helen Evelina Siringoringo,

email:helenevelina@gmail.com, Telp: 085279775999

\section{PENDAHULUAN}

Preeklampsia menyebabkan kematian ibu hamil sekitar $18 \%$ terbesar kedua di dunia. Sampai sekarang, penyakit preeklampsia/eklampsia masih merupakan masalah obstetri yang belum dapat terpecahkan secara tuntas. ${ }^{1,2}$

Preeklampsia-eklampsia sampai saat ini masih merupakan disease of theory. Beberapa kelainan yang terjadi pada preeklamsia antara lain iskemia plasenta, vasopasme umum, hemostatis abnormal dengan aktivasi sistem koagulasi, disfungsi endotel vaskular, aktivasi leukosit, perubahan dalam berbagai sitokin serta resistensi insulin, nitrat oksida normal dan metaboisme lipid. Berbagai macam penelitian belum dapat menerangkan dengan jelas penyebab pasti preeklampsia-eklampsia. Akibatnya, sampai saat ini belum ada pengobatan definitif pada kelainan ini. ${ }^{2,3}$

Pada preeklampsia terjadi kegagalan invasi selsel trofoblas sehingga lapisan otot arteri spiralis menjadi tetap kaku dan keras sehingga lumen arteri spiralis mengalami vasokonstriksi. Hal ini menyebabkan aliran darah utero plasenta menurun dan terjadilah hipoksia dan iskemia plasenta. Plasenta yang mengalami hipoksia dan iskemia akan menghasilkan oksidan. Salah satu oksidan penting yang dihasilkan adalah radikal hidroksil. Radikal hidroksil akan merusak membran sel yang mengandung banyak asam lemak tidak jenuh menjadi lipid peroksida. Lipid peroksida ini akan merusak membrane sel endotel yang mengakibatkan terganggunya fungsi endotel. Keadaan ini disebut disfungsi endotel. Disfungsi endotel akan menyebabkan gangguan multi organ. ${ }^{4}$

Disfungsi endotel ini juga dapat disebabkan oleh perubahan profil lipid diantaranya yaitu Low Density Lipoprotein (LDL) dan High Density Lipoprotein (HDL). Diduga terdapat hubungan antara preeklampsia terhadap peningkatan rasio LDL dan HDL .5 Peningkatan rasio LDL/HDL menyebabkan disfungsi endotel. Pada disfungsi endotel terjadi ketidakseimbangan produksi zat-zat vasodilator seperti prostasiklin dan nitrat oksida dengan vasokonstriktor seperti tromboxan dan endotelium I sehingga akan terjadi vasokonstriksi yang luas dan terjadilah preeklampsia. Pada preeklampsia terjadi gangguan pada vaskularisasi dari unit fetoplacental, sehingga terjadi mekanisme yang dapat meningkatkan sintesis kadar trigliserida maternal serta penurunan katabolisme trigliserida. ${ }^{6-8}$

Pengaturan pola makan dan modifikasi diet merupakan salah satu cara untuk membantu dalam menekan peningkatan kadar lipid darah. Pola konsumsi sangat berkaitan dengan faktor-faktor yang dapat mempengaruhi kadar kolesterol dan trigliserida dalam darah misalnya dengan seringnya mengkonsumsi makanan yang mengandung lemak jenuh dan kurang mengkonsumsi makanan yang mengandung serat. $^{9}$ Keadaan ini terjadi pada masyarakat Sumatera Barat yang olahan makanannya banyak mengandung lemak seperti menggunakan santan kepala dan gorengan. Etnik Minangkabau mengkonsumsi lemak 10,6-21,7\% dari energi total dengan asam lemak jenuh (ALJ) 18\%. ${ }^{10}$ Asupan ALJ pada etnik Minangkabau lebih tinggi dari yang dianjurkan. $^{11}$ Pada tahun 2011 Hatma pada penelitiannya mengatakan bahwa etnik Minangkabau memiliki kadar total kolesterol $(209,77 \mathrm{mg} / \mathrm{dl})$ dan kadar LDL (146.02 mg/dl) lebih tinggi dari etnik Sunda, Jawa dan Bugis. Sementara kadar HDL (36.79 mg/dl) paling rendah pada etnik Sunda.

Tujuan penelitian ini adalah untuk mengetahui perbedaan rerata kadar profil lipid pada preeklampsia dengan kehamilan normal pada etnik Minangkabau.

\section{METODE}

Penelitian ini merupakan penelitian analitik observasional dengan desain cross sectional comparative untuk mengetahui perbedaan rerata kadar profil lipid pada preeklampsia dengan kehamilan normal pada etnik Minangkabau. Penelitian ini dilakukan di ruang kebidanan dan Laboratorium RS dr. M. Djamil Padang, RS dr. Reksodiwiryo Padang dan UPTD Balai Laboratorium Kesehatan Provinsi Sumatera Barat. Penelitian dilakukan mulai Agustus sampai dengan Desember 2014. 
Populasi penelitian ini adalah seluruh ibu hamil trimester III. Subjek penelitian yang dipilih adalah semua populasi yang memenuhi kriteria inklusi dan eksklusi. Kriteria inklusi dalam penelitian ini adalah ibu hamil normal trimester III, ibu hamil dengan preeklampsia, ibu hamil normal dan preeklampsia etnik Minangkabau. Kriteria eksklusi adalah ibu hamil dengan diabetes mellitus, ibu hamil kembar,dan ibu hamil dengan penyakit jantung koroner.

Jumlah subjek dihitung dengan menggunakan rumus uji hipotesis terhadap rerata dua populasi independen.

$$
\mathrm{n}_{1}=\mathrm{n}_{2}=2 \frac{\{(Z \alpha+Z \beta) S\}^{2}}{\mathrm{X}_{1}-\mathrm{X}_{2}{ }^{2}}
$$

Ket :

$\mathrm{N} \quad$ : Besarnya sampel untuk tiap kelompok

Za : Kesalahan tipe I ( $\alpha$ ) sebesar $5 \%=1,96$

Z $\beta \quad$ Kesalahan tipe II $(\beta)$ sebesar $20 \%=0,842$

$\mathrm{S} \quad$ : Simpangan baku dari penelitian sebelumnya (10)

X1-X2 : Selisih nilai mean pada kelompok kasus dan control $(11,1)$

Jumlah masing-masing subjek pada tiap kelompok adalah 27 orang sehingga jumlah subjek minimal keseluruhan yang dibutuhkan adalah 54 sampel. Pengambilan subjek menggunakan metode non probability sampling dengan cara consecutive sampling.

Pemeriksaan kadar profil lipid dilakukan dengan cara pengambilan darah vena mediana cubity sebanyak $3 \mathrm{cc}$ dengan spuit $3 \mathrm{ml}$, kemudian disentrifus dan selanjutnya dilakukan pengukuran kadar profil lipid (total kolesterol, trigliserida, HDL, dan LDL) dengan metode kalorimetri. Data kadar profil lipid dianalisis dengan menggunakan uji independent $t$-test.

\section{HASIL}

Didapatkan sebanyak 54 orang ibu hamil yang memenuhi kriteria inklusi. 27 orang ibu hamil dengan preeklampsia dan 27 orang ibu hamil dengan kehamilan normal.
Tabel 1. Distribusi frekuensi kelompok preeklampsia dan kehamilan normal berdasarkan karakteristik responden

\begin{tabular}{|c|c|c|c|c|c|c|c|}
\hline \multirow[t]{4}{*}{ Karakteristik } & \multicolumn{6}{|c|}{ Kelompok } & \multirow{4}{*}{ p } \\
\hline & \multicolumn{3}{|c|}{ Preeklampsia } & \multicolumn{2}{|c|}{$\begin{array}{c}\text { Kehamilan } \\
\text { Normal }\end{array}$} & & \\
\hline & \multicolumn{3}{|c|}{$n=27$} & \multicolumn{2}{|c|}{$\mathrm{n}=\mathbf{2 7}$} & & \\
\hline & $f$ & $\%$ & & & & & \\
\hline \multicolumn{8}{|l|}{ Usia ( Tahun) } \\
\hline $20-35$ & 18 & 66,7 & & 21 & 77,8 & & \\
\hline$>35$ & 9 & 33,3 & & 6 & 22,2 & & \\
\hline Min & & & 21 & & & 21 & \\
\hline Max & & & 41 & & & 48 & \\
\hline Mean \pm SD & & & $\begin{array}{l}32,7 \pm \\
5,986\end{array}$ & & & $\begin{array}{c}30,15_{ \pm} \\
6,485\end{array}$ & 0,138 \\
\hline \multicolumn{8}{|l|}{ Gravida } \\
\hline Primi & 5 & 18,5 & & 13 & 48,1 & & \\
\hline Multi & 20 & 74,1 & & 13 & 48,1 & & \\
\hline Multigrande & 2 & 7,4 & & 1 & 3,7 & & \\
\hline Min & & & 1 & & & 1 & \\
\hline $\operatorname{Max}$ & & & 8 & & & 5 & \\
\hline Mean \pm SD & & & $2,81 \pm$ & & & $1,93 \pm$ & 0.121 \\
\hline & & & 1,570 & & & 1,141 & \\
\hline
\end{tabular}

Tabel 1 menunjukkan bahwa rerata usia responden pada kelompok preeklampsia dan kehamilan normal secara berturut-turut adalah $32,7 \pm 5,986$ tahun dan $30,15 \pm 6,485$ tahun. Rerata

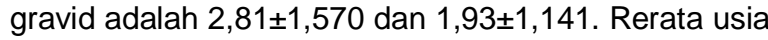
dan gravida responden menunjukkan tidak terdapat perbedaan bermakna antara kelompok preeklampsia dengan kehamilan normal dengan nilai $p=0,138$ dan $\mathrm{p}=0,121$.

Tabel 2 menunjukkan bahwa rerata kadar total kolesterol pada kelompok preeklampsia dan kehamilan normal adalah 270,19+68,955 mg/dL dan $247,56 \pm 44,415 \mathrm{mg} / \mathrm{dL}$ dengan nilai $\mathrm{p}=0,158$, rerata kadar trigliserida pada kelompok preeklampsia dan kehamilan normal adalah 296,07 $\pm 157,993 \mathrm{mg} / \mathrm{dL}$ dan $272,89 \pm 84,608 \mathrm{mg} / \mathrm{dL}$ dengan nilai $p=0,504$, rerata kadar HDL pada kelompok preeklampsia dan kehamilan normal adalah 51,93 $\pm 19,882 \mathrm{mg} / \mathrm{dL}$ dan $63,33 \pm 11,222 \mathrm{mg} / \mathrm{dL}$ dengan nilai $\mathrm{p}=0,012$, rerata kadar LDL pada kelompok preeklampsia dan kehamilan normal adalah $159 \pm 52,038 \mathrm{mg} / \mathrm{dL}$ dan $129,67 \pm 38,692 \mathrm{mg} / \mathrm{dL}$ dengan nilai $\mathrm{p}=0,023$, rasio perbandingan LDL/HDL pada kelompok preeklampsia dan kehamilan normal adalah 3,86 dan 2,04 dengan nilai $p=0,005$ 
Tabel 2. Perbedaan rerata kadar profil lipid pada preeklampsia dengan kehamilan normal

\begin{tabular}{|c|c|c|c|c|c|c|c|}
\hline \multicolumn{8}{|c|}{ Kelompok } \\
\hline \multirow[t]{2}{*}{ Variabel } & \multicolumn{3}{|c|}{ Preeklampsia $\mathbf{n = 2 7}$} & \multicolumn{3}{|c|}{ Kehamilan Normal n=27 } & \multirow[t]{2}{*}{$\mathbf{p}$} \\
\hline & Mean $_{ \pm}$SD & Min & Max & Mean+SD & Min & Max & \\
\hline Total Kolesterol (mg/dL) & $270,19 \pm 68,955$ & 104 & 398 & $247,56 \pm 44,415$ & 169 & 326 & 0.158 \\
\hline Trigliserida (mg/dL) & $296,07 \pm 157,993$ & 111 & 588 & $272,89 \pm 84,608$ & 125 & 448 & 0,504 \\
\hline $\mathrm{HDL}(\mathrm{mg} / \mathrm{dL})$ & $51,93 \pm 19,882$ & 7 & 86 & $63,33 \pm 11,222$ & 43 & 96 & 0,012 \\
\hline LDL (mg/dL) & $159 \pm 52,038$ & 48 & 252 & $129,67 \pm 38,692$ & 57 & 198 & 0,023 \\
\hline LDL/HDL & $3,86 \pm 3,09$ & 1,41 & 16,29 & $2,08 \pm 0,64$ & 1,09 & 3,36 & 0,005 \\
\hline
\end{tabular}

\section{PEMBAHASAN}

Ada banyak faktor risiko untuk terjadinya preeklampsia antara lain primigravida, primipaternitas dan usia ibu yang ekstrim, yaitu kurang dari 20 tahun atau lebih dari 35 tahun. $^{2}$ Insiden preeklampsia tertinggi pada wanita hamil dengan usia paling muda. Ada hubungan yang bermakna antara umur wanita hamil dengan preeklampsia. Umur yang kurang dari 20 tahun mempunyai resiko terjadi preeclampsia, ibu hamil $<20$ tahun mudah mengalami kenaikan tekanan darah dan lebih cepat menimbulkan kejang, sedangkan umur > 35 tahun juga merupakan faktor predisposisi untuk terjadinya preeklampsia karena bertambahnya usia juga lebih rentan untuk terjadinya peningkatan insiden hipertensi kronis dan menghadapi risiko lebih besar untuk menderita hipertensi karena kehamilan. $^{12}$ Usia ibu yang semakin tua akan menyebabkan terjadinya penebalan dari lapisan intima. Kandungan lipid, terutama kolesterol dan fosfolipid juga secara progresif meningkat dengan bertambahnya usia. Bentuk pembuluh darah menjadi lebih besar, berkelok-kelok dan terjadi aneurisma. Wanita primigravida memiliki insidensi hampir dua kali lipat mengalami preeklampsia dibanding dengan multipara. Angka kejadian preeklampsia tinggi pada primigravida, muda maupun tua. Kehamilan dengan preeklampsia lebih umum terjadi pada primigravida, keadaan ini disebabkan secara imunologik pada kehamilan pertama terjadi pembentukan blocking antibodies terhadap antigen plasenta tidak sempurna sehingga timbul respon imun yang tidak menguntungkan terhadap histoincompability plasenta. $^{13}$

Kolesterol total adalah hitungan total dari semua jenis kolesterol dalam darah. Kolesterol total sebenarnya merupakan susunan dari banyak zat, termasuk trigliserida, LDL dan HDL.
Kolestrol tidak larut dalam darah sehingga perlu berikatan dengan pengangkutnya, yaitu lipoprotein. ${ }^{14}$ Hasil penelitian Padmini pada tahun 2011 menunjukan terjadinya peningkatan kadar kolesterol total dalam serum tali pusat pada kelompok kasus dibandingkan dengan kelompok kontrol. Hal ini menggambarkan terjadinya hiperkolesterolemia. Asam lemak bebas juga meningkat pada kelompok kasus, mungkin disebabkan oleh peningkatan aktivitas lipase dengan konsekuensi pelepasan asam lemak bebas dari adiposit ke sirkulasi. Asam lemak ini dilaporkan berkontribusi terhadap disfungsi endotel. ${ }^{15}$

Etnik Minangkabau mengkonsumsi lemak 10,621,7\% dari energi total dengan ALJ 18\%. Asupan ALJ pada etnik Minangkabau lebih tinggi dari yang dianjurkan. Etnik Minangkabau memiliki kadar kolesterol total 209, $77 \mathrm{mg} / \mathrm{dL}$, lebih tinggi dari etnik Sunda, Jawa dan Bugis. ${ }^{10,11}$

Pada kehamilan terjadi perubahan profil lemak yaitu peningkatan trigliserida yang diikuti peningkatan lemak lain. Hal ini disebabkan peningkatan satu jenis lemak akan membutuhkan lemak lain guna pembentukan yang sesuai dengan bentuk strukturnya. Hipertrigliserida mengakibatkan perubahan spektrum IDL (Intermediate Density Lipoprotein) menjadi partikel LDL berukuran lebih kecil, memiliki densitas lebih tinggi dan bersifat aterogenik. ${ }^{16,17}$

Masih belum jelas apakah hipertrigliseridemia menjadi faktor risiko preeklampsia atau apakah ada hubungan penyebab diantaranya, kadar trigliserida yang tinggi tampaknya meningkatkan risiko gangguan pembuluh darah plasenta, yang memicu disfungsi endotel, aterosklerosis dan trombosis. Perkembangan aterosklerosis pada arteri spiralis plasenta wanita preeklampsia menunjukkan bahwa peningkatan kadar trigliserida terlibat dalam gangguan ini. ${ }^{18}$ Perubahan 
sintesis lipid menyebabkan penurunan rasio PGI2: TXA2 juga seharusnya menjadi langkah penting untuk patogenesis pada hipertensi dalam kehamilan. Jadi metabolisme lipid yang tidak normal tampaknya memiliki peran penting dalam patogenesis hipertensi dalam kehamilan. ${ }^{19}$

Makanan yang mengandung lemak akan meningkatkan kadar trigliserida dalam darah cenderung meningkatkan kadar kolesterol. Lemak yang berasal dari buah-buahan seperti kelapa yang banyak dikonsumsi pada olahan makanan etnik Minangkabau, tidak mengandung kolesterol tetapi kadar trigliseridanya tinggi. Hal ini menyebabkan kadar trigliserida pada etnik Minangkabau tinggi.

HDL merupakan salah satu dari tiga komponen lipoprotein yaitu kombinasi lemak dan protein, mengandung kadar protein tinggi, sedikit trigliserida dan fosfolipid, mempunyai sifat umum protein dan terdapat pada plasma darah, disebut juga lemak baik yang membantu membersihkan penimbunan plak pada pembuluh darah. ${ }^{20}$

Pada tahun 2011, Hatma mendapatkan bahwa kadar HDL pada etnik Minangkabu 36,79 mg/dL, lebih rendah dari etnik Jawa dan Sunda. ${ }^{21}$ Partikel HDL membawa kolesterol dari perifer jaringan ke hati. Gangguan transportasi kolesterol dari jaringan perifer ke area target dapat menyebabkan penurunan HDL dalam serum. Hipertrigliseridemia menyebabkan kadar HDL rendah. ${ }^{22}$

LDL merupakan lipoprotein yang mengangkut paling banyak kolesterol dalam darah. Kadar LDL yang tinggi menyebabkan pengendapan kolesterol dalam arteri. Kolesterol LDL mengandung kolesterol ester yang dominan dalam intinya, tetapi kadar trigliserida hanya kurang dari 10\%. Dalam situasi hipertrigliseridemia, kolesterol LDL akan mampu menyerap trigliserida lebih banyak lagi. Hal tersebut akan menghasilkan kolesterol LDL kecil dan padat yang bersifat aterogenik. ${ }^{23,24}$

Sel-sel tubuh memerlukan koleterol untuk tumbuh dan berkembang sebagaimana mestinya. Selsel ini memperoleh kolesterol dari LDL. Etnik Minangkabau memiliki kadar LDL 146,02 mg/dL lebih tinggi dari etnik Sunda, Jawa dan Bugis. Semakin banyak lemak jenuh atau makan makanan yang mengandung kolesterol tinggi akan mengakibatkan kadar kolesterol dalam darah tinggi yang juga akan meningkatkan kadar LDL. ${ }^{25}$

Peningkatan kadar LDL dan penurunan kadar HDL pada wanita dengan preeklampsia pada awalnya disebabkan oleh tingginya konsentrasi trigliserida dalam plasma darah. Pada preeklampsia didapatkan aktivitas hepatic lipase yang meningkat sehingga mengakibatkan konsentrasi trigliserida semakin tinggi. Konsentrasi trigliserida yang tinggi mengakibatkan semakin banyak terbentuk small dense LDL dan penurunan aktivitas $\mathrm{HDL}^{26}$ Small dense LDL merupakan LDL yang berukuran kecil dan memiliki densitas yang tinggi merupakan salah satu jenis lipoprotein utama yang menyebabkan terjadinya preeklampsia. Semakin kecil diameter LDL, densitas LDL semakin padat dan semakin mudah teroksidasi. Begitu teroksidasi LDL yang berukuran kecil ini berpotensi tinggi untuk menyebabkan pembuluh darah menjadi lebih mudah membentuk atherom, pembentukan sel busa meningkat, dan mengakibatkan terjadinya disfungsi endotel. ${ }^{26,27}$

\section{KESIMPULAN}

Tidak ada perbedaan kadar kolesterol total dan trigliserida pada preeklampsia dengan kehamilan normal pada etnik Minangkabau, ada perbedaan kadar HDL dan LDL pada preeklampsia dengan kehamilan normal pada etnik Minangkabau, rasio perbandingan LDL/HDL lebih tinggi pada preeklampsia daripada kehamilan normal.

\section{UCAPAN TERIMA KASIH}

Terima kasih kepada direktur dan staf $\mathrm{RS}$ dr. M. Djamil Padang, direktur dan satf $R S d r$. Reksodiwiryo Padang, Kepala dan satf UPTD Balai Laboratorium Kesehatan Provinsi Sumatera Barat sebagai tempat penelitian atas fasilitas yang telah diberikan.

\section{DAFTAR PUSTAKA}

1. Wibowo N. Patogenesis preeklampsia. Prosiding seminar konsep mutakhir preeclampsia. Jakarta: Indonesia; 2007.

2. Cunningham FG, Leveno KJ, Bloom SI, Hauth JC, Rouse DJ, Spong CY. Obstetri Williams. Edisi ke23. Volume 2. Jakarta: EGC; 2012. 
3. Sibai. Diagnosis and management of gestational hypertension and preeclampsia. 2003 (diunduh 17 Desember 2013). Tersedia dari: URL: HYPERLINK http://www.utilis.net/obstetric/sibai-GHTN.pdf

4. Prawirohardjo S. Hipertensi dalam kehamilan. Dalam: Ilmu kebidanan. Jakarta: Yayasan Pustaka Sarwono Prawirohardjo; 2010. hlm.531-59.

5. William TF, Robert IL, Donald SF. Estimation of the concentration of low density lipoprotein kholesterol in plasma, without use of the preparative ultracentrifuge. Clinical chemistry. 2004;(18):499502.

6. Mauro P, Rodrigo R. Screning test for preeclamsia through assesment of uteroplacental blood flow and biochemical markers of oxidative stress and endothelial dysfunction. American journal of obstetrics and gynecology. 2005;193(4):1486-91.

7. Yeasmin F, Mahal M, Amin S, Shahnaj A, Rashid M, Hossain MS. Association of serum homocysteine and serum lipid with eclampsia. Journal Medical Clinical Bangladesh. 2009;(3):7-9.

8. Kashinakunti SV, Sunitha H, Gurupadappa K, Manjula R. Lipid profile in preeclampsia-A case control study. Journal of Clinical and Diagnostic Research. 2010;(4): 2748-51.

9. Mayes PA. Sintesis, pengangkutan, dan ekskresi kolesterol. Dalam: Biokimia Harper (terjemahan) . Jakarta: EGC;25:239-49.

10. Liputo NI, Agus Z, Oenzil F, Masrul M. Contemporary Minangkabau food culture in West Sumatera Indonesia. Asia Pacific J Clin Nutr. 2001;10(1):10-6.

11. Sulastri D. Pola asupan lemak, serat dan antioksidan serta hubungannya dengan profil lipid pada laki-laki Etnik Minangkabau. Majalah Kedokteran Indonesia. 2005;55(2).

12. Rachimhadi. Peranan bidan dalam penanganan $\mathrm{EPH}$ gestosis. Majalah Kesehatan Indonesia. Jakarta; 2008.

13. Yuliawati. Analisis faktor risiko yang mempengaruhi terjadinya preeklampsia di rumah sakit Pandan Arang Boyolali Tahun 1998-2000 (tesis). Yogyakarta: Universitas Gadjah Mada; 2001.

14. Anwar TB. Dislipidemia sebagai faktor risiko penyakit jantung koroner. USU repository: 2004

15. Padmini E, Usha RM. Lipid profil alterations and oxidative stress in patients with preeclampsia. Role of black tea extract on disease management.Turk J Med Sci. 2011;5(41):761-68.

16. Kane JP, Malloy. Metabolism lipoprotein disolder basic and clinical endocrinology. 2000;4; 848-58.

17. Robert JM, Balk JL, Bodnar, LM Belizan, JM Berger E, Martinez A. Nutrient involeuement in PE. Am-I of clinical NNutrion. 2003; 16845-925.

18. De Lima VJ, de Andrade CR, Ruschi GE, Sass N. Serum lipid levels in pregnancies complicated by preeclampsia. Sao Paulo Med J. 2011;129(2):73-6.

19. Islam NAF, MAR Choowdhury, GM Kibria, S Akhter. Study of serum lipid in pre-eclampsia and eclampsia. 2010;(5)2:56-9.

20. Sutedjo AY. Buku saku mengenal penyakit melalui pemeriksaan laboratorium. Yogyakarta: Amara Book; 2008.

21. Hatma RD. Lipid profiles among diverse ethnic groups in Indonesia. Department of Epidemiology. Jakarta. Faculty of Public Health, University of Indonesia. 2011;43(1)

22. Aziz R, Mahboob T. Pre-eclampsia and lipid profile. Pak J Med Sci October. 2007;23(5): 751-4.

23. Soeharto Iman. Serangan jantung dan stroke hubungannya dengan lemak dan kolesterol, Jakarta: Gramedia Pustaka Utama; 2004.

24. Santoso A. Lipid dan penyakit jantung koroner. Centra Commucations. 2009.

25. Winkler K, Konrad T, Fullert S, Friedrich I, Destani $\mathrm{R}$, Baumstark MW, et al. Pioglitazone reduces atherogenic dense LDL particles in nondiabetic patients with arterial hypertension: a double blind, placebo-controlled study. Atherosclerosis. 2003;162(2):425-32.

26. Belo L, Caslake M, Gaffney D, Santos-Silva A, Pereira-Leite L, Quintanilha A. Changes in LDL size and HDL concentration in normal and preeclamptic pregnancies. Rebelo Diabetes Care. 2002 ;26(9):2588-94.

27. Jayante, De Kumar, A. Saha P. Study of serum lipid profile in pregnancy induced hypertension. Indian Journal of Clinical Biochemistry. 2006; 21(2):165-8. 